\title{
Endocrine-disrupting Chemicals: Review of Toxicological Mechanisms Using Molecular Pathway Analysis
}

\author{
Oneyeol Yang ${ }^{1,2}$, Hye Lim Kim ${ }^{1,2}$, Jong-II Weon ${ }^{2,3}$, Young Rok Seo ${ }^{1,2}$ \\ 'Department of Life Science, College of Life Sciences and Biotechnology, Dongguk University Biomedi Campus, Goyang, ${ }^{2}$ Institute of Environmental \\ Medicine, Dongguk University Biomedi Campus, Seoul, ${ }^{3}$ Department of Safety Engineering, Dongguk University College of Natural Science, \\ Gyeongju, Korea
}

\begin{abstract}
Endocrine disruptors are known to cause harmful effects to human through various exposure routes. These chemicals mainly appear to interfere with the endocrine or hormone systems. As importantly, numerous studies have demonstrated that the accumulation of endocrine disruptors can induce fatal disorders including obesity and cancer. Using diverse biological tools, the potential molecular mechanisms related with these diseases by exposure of endocrine disruptors. Recently, pathway analysis, a bioinformatics tool, is being widely used to predict the potential mechanism or biological network of certain chemicals. In this review, we initially summarize the major molecular mechanisms involved in the induction of the above mentioned diseases by endocrine disruptors. Additionally, we provide the potential markers and signaling mechanisms discovered via pathway analysis under exposure to representative endocrine disruptors, bisphenol, diethylhexylphthalate, and nonylphenol. The review emphasizes the importance of pathway analysis using bioinformatics to finding the specific mechanisms of toxic chemicals, including endocrine disruptors.
\end{abstract}

(J Cancer Prev 2015;20:12-24)

Key Words: Endocrine disruptors, Molecular mechanism, Obesogen, Pathway analysis

\section{INTRODUCTION}

Endocrine disruptors are chemicals that interfere with the hormone systems and produce adverse developmental, reproductive, neurological, and immunological effects in mammals. Endocrine disruptors can be found in many products including plastic bottles, metal food cans, detergents, flame retardants, food, toys, cosmetics, and pesticides. Although limited scientific information is available on the potential adverse human health effects, concern arises because endocrine disrupting chemicals presenting in the environment at very low levels have been shown to have adverse effects. Some research shows that these substances are also adversely affecting human health in similar ways, resulting in reduced fertility and increased progression of some diseases, including obesity, diabetes, endometriosis, and some cancers. These chemicals have also been referred to as endocrine modulators, environmental hormones, and endocrine active compounds. ${ }^{1}$ Because the hazards of endocrine disruptors are well known, a more complete study of the molecular mechanism is needed.

To analyze their different mechanisms, comprehensive analysis is required. As a typical comprehensive analysis in biology, pathway analysis can be efficient. Today, the quality and quantity of biological data are increasing. To process the large amount of data, a new field called bioinformatics has developed. Pathway analysis is one of bioinformatics tools whose goal is to identify the pathways significantly impacted. Pathway analysis has become the first choice for gaining insight into the underlying biology of genes and proteins that are differentially expressed. Through pathway analysis, researchers can find the direct

Received February 18, 2015, Accepted March 14, 2015

Correspondence to: Young Rok Seo

Department of Life Science, College of Life Sciences and Biotechnology, Dongguk University Biomedi Campus, 32 Dongguk-ro, Ilsandong-gu, Goyang 410-820, Korea Tel: +82-31-961-5131, Fax: +82-31-961-5348, E-mail: seoyr@dongguk.edu

Copyright (C) 2015 Korean Society of Cancer Prevention

(c) This is an Open Access article distributed under the terms of the Creative Commons Attribution Non-Commercial License (http://creativecommons. org/icenses/by-nc/3.0) which permits unrestricted non-commercial use, distribution, and reproduction in any medium, provided the original work is properly cited. 
interactions, find the shortest paths, functionally group pathways, find the shortest pathway between selected genes/proteins, and find Primary/Secondary/Tertiary relationships. Finally, it can infer molecular mechanisms.

In this review, we summarize the known molecular mechanisms of endocrine disruptors focusing on cancer and obesity, and arrange the molecular mechanisms studies using pathway analysis focusing on bisphenol A (BPA), nonylphenol (NP), Di-(2-ethylhexyl) phthalate (DEHP) as representative endocrine disruptors.

\section{EXPOSURE AND REGULATION OF ENDOCRINE DISRUPTORS}

Food is the major route of exposure to endocrine disruptors
(Fig. 1A). According to an article reported by Schecter et al., ${ }^{2}$ a total of 32 food samples from three major supermarket chains in Dallas were contaminated with polybrominated diphenyl esters (PBDEs). In this study, PBDEs are detected mainly in fish, meat, and dairy products. BPA exposure also occurs through diet, including contaminated food and water. ${ }^{3}$

The increase in household products containing pollutants and the decrease in building ventilation indoor air to become a significant source of endocrine disruptor exposure. ${ }^{4}$ In addition, endocrine disruptors accumulate from a variety of routes in the body (Fig. 1B). ${ }^{5}$ Phthalates are easily released into the environment and it is known that exposure of phthalates in the air induce asthma in children. ${ }^{6}$ NPs are produced industrially, naturally, and by the environmental degradation of alkylphenol

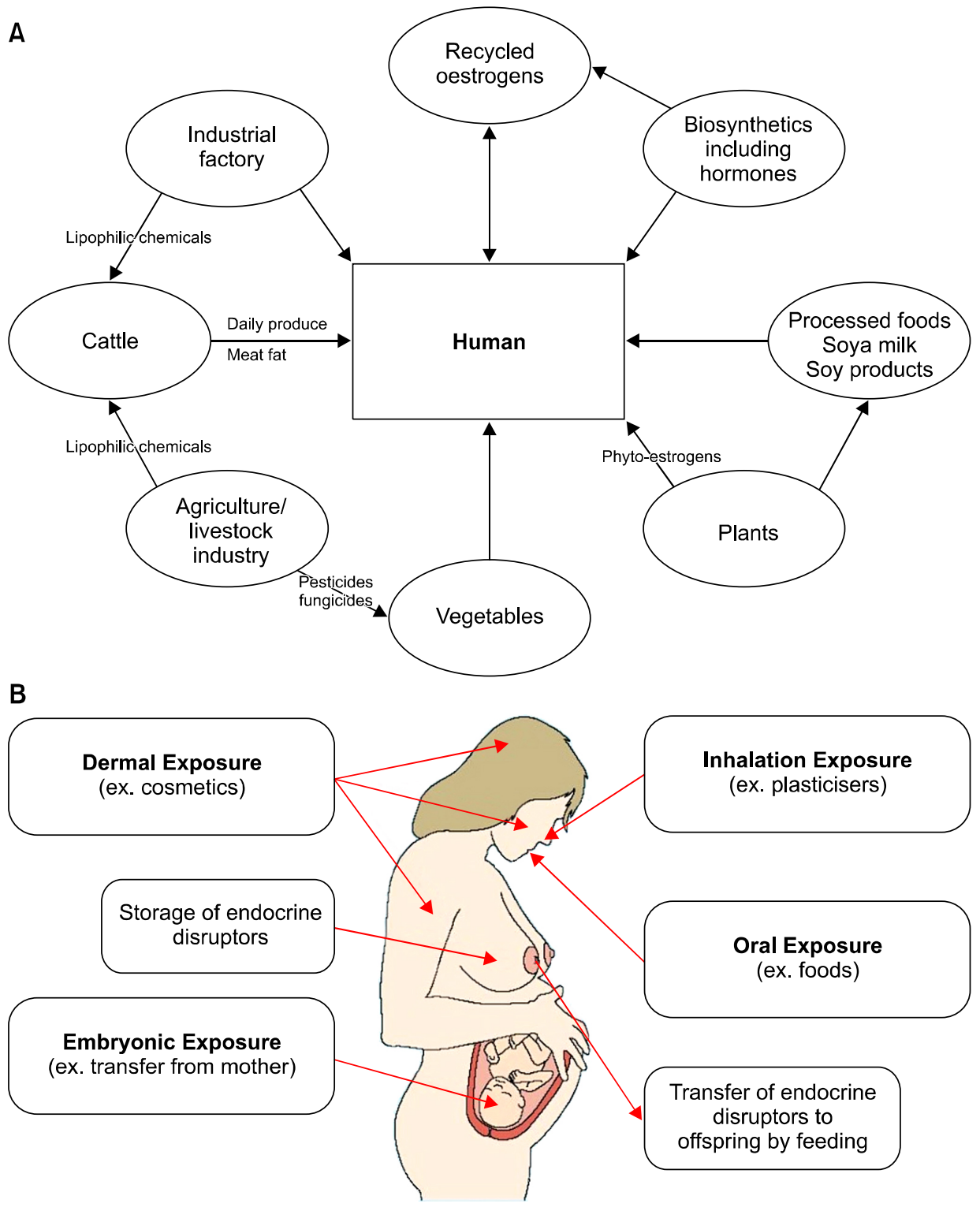

Figure 1. Exposure sources and routes of endocrine disruptors in human. (A) Humans are exposed to endocrine disruptors directly or indirectly. Direct is through raw substance such as pharmaceutical including endocrine disruptors and phytoestrogens in plants. Indirect is exposure from foods treated with endocrine disruptors like pesticides and fungicides. (B) The major routes of human exposure. The fetus can be exposed by endocrine disruptors from the mother through the blood and breast milk. Cited from the article of Sharpe and Irvine (BMJ 2004:328:44751) with original copyright holder's permission. ${ }^{5}$ 
Table 1. International organizations and chemical agents including endocrine disruptor

\begin{tabular}{|c|c|c|c|}
\hline Organization & $\begin{array}{l}\text { Establish- } \\
\text { ment }\end{array}$ & Composition & Major activity \\
\hline $\begin{array}{l}\text { Organization for } \\
\text { Economic Cooperation } \\
\text { and Development } \\
\text { (OECD) }\end{array}$ & 1971 & $\begin{array}{l}\text { USA, Japan, } \\
\text { European Union (EU), et al. } \\
\text { ( } 29 \text { nations) }\end{array}$ & $\begin{array}{l}\text { - Mutual recognition and enforcement between member states Good } \\
\text { Laboratory Practice adjustment } \\
\text { - Chemicals related to mutual information exchange } \\
\text { - Systematic investigation of existing chemicals and database screen } \\
\text { - Environmental hazard assessment of new chemicals } \\
\text { - Right to participate in the local population to ensure the chemical- } \\
\text { related policy decisions }\end{array}$ \\
\hline $\begin{array}{l}\text { United Nations } \\
\text { Environment Programme } \\
\text { (UNEP) Chemicals [IRPTC] }\end{array}$ & 1976 & United Nations (UN) & $\begin{array}{l}\text { - Create a comprehensive database of information on chemicals } \\
\text { - Build an international network for the exchange of information } \\
\text { - International notification system for the regulation of chemicals } \\
\text { international promotion } \\
\text { - Data exchange 'London Guideline' for the implementation of the } \\
\text { information exchange of international trade, such as chemical }\end{array}$ \\
\hline $\begin{array}{l}\text { International Programme } \\
\text { on Chemical Safety (IPCS) }\end{array}$ & 1980 & $\begin{array}{l}\text { UN, International Labour } \\
\text { Organization (ILO), } \\
\text { World Health } \\
\text { Organization (WHO) }\end{array}$ & $\begin{array}{l}\text { - Risk assessment and development of the various test methods on } \\
\text { human health and the environment by exposure to the chemical } \\
\text { - Addiction prevention and promotion of international cooperation } \\
\text { and technical assistance activities with developing countries for } \\
\text { the treatment and training } \\
\text { - Promote international cooperation to respond to chemical incidents }\end{array}$ \\
\hline $\begin{array}{l}\text { Intergovernmental Forum } \\
\text { on Chemical Safety (IFCS) }\end{array}$ & 1994 & UN, ILO, WHO & $\begin{array}{l}\text { - Enlargement and strengthening of the international assessment of } \\
\text { chemical risks } \\
\text { - Combination for classification and labeling of chemical } \\
\text { - Information exchange on toxic chemicals and chemical risks } \\
\text { - Risk reduction plan } \\
\text { - Strengthening of national capabilities and facilities for chemicals } \\
\text { management } \\
\text { - Preventing illegal trade in hazardous chemicals }\end{array}$ \\
\hline
\end{tabular}

Cited from the article of Yeo (Korean Institute of Criminology) with original copyright holder's permission. ${ }^{11}$

ethoxylates. It originates principally from the degradation of NP ethoxylates which are widely used as industrial surfactants. ${ }^{7}$

Several environmental substances including heavy metals which seem to act as endocrine disruptors are reported. Numerous studies have demonstrated that tissues including kidney, liver and testis are sensitive to heavy metals toxicity. ${ }^{8}$ Heavy metals are released into the environments from industrial and agricultural products. ${ }^{9}$ Particularly, exposure through tobaccos is major source to human exposure with heavy metals. ${ }^{10}$

With identifying evidence of the harmfulness of endocrine disruptors, their use is heavily restricted and the human body burden of the endocrine disruptors decline. The first step in reducing the body burden is eliminating or phasing out their production. The second step toward lowering human body burden is awareness of and labeling of foods that are likely to contain high amounts of endocrine disruptors. Endocrine disruptors were first discussed as a global issue at the 'Rio summit' in 1992. 'Agenda 21' was adopted at the summit and focuses on environmental safety management is of toxic and dangerous agents. Since that summit, endocrine disruptors have been regulated by various international organizations (Table 1). ${ }^{11}$ BPA has been controlled by restricting policy in countries around the world. This policy applies to World Health Organization as well as individual countries. ${ }^{12}$ The use of some phthalates has been restricted in the European Union (EU) since 1999 and in the United States since 2008. ${ }^{13,14} \mathrm{NP}$ also is prohibited in the EU, the USA, and in other countries. ${ }^{7,15}$

\section{MOLECULAR MECHANISMS WITH ENDOCRINE DISRUPTORS}

In general, endocrine disruptors are thought to affect an organism's endocrine system. Additionally endocrine disruptors are known to affect other diseases such as cancer and obesity (Fig. 2). ${ }^{16-18}$ In the case of obesity, endocrine disruptors are called obesogens. This chapter deals with molecular mechanisms of endocrine disruptors already studied.

\section{Inhibition of endocrine receptors}

Endocrine disruptors can affect every level of the endocrine 
A

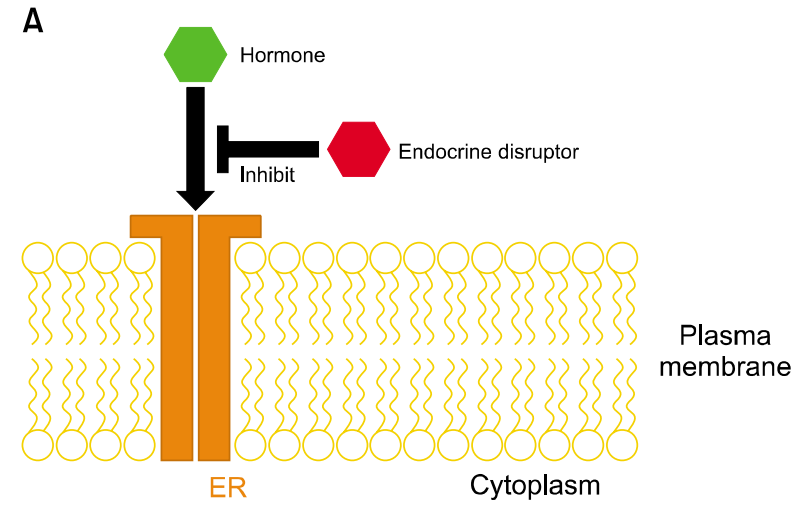

B

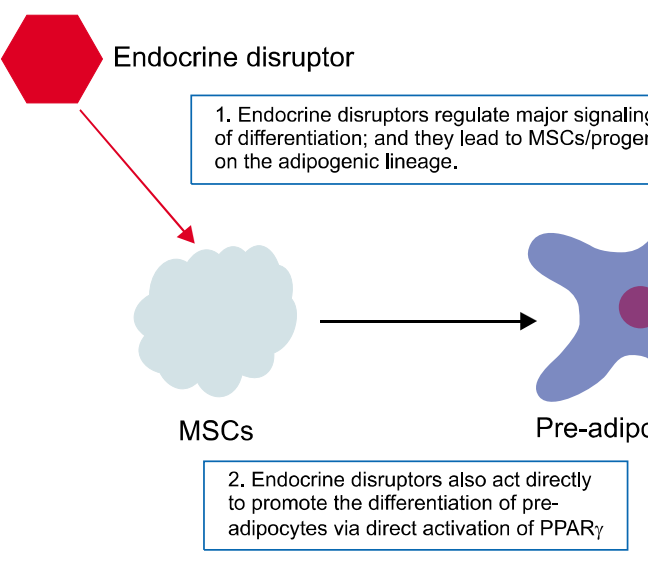

C

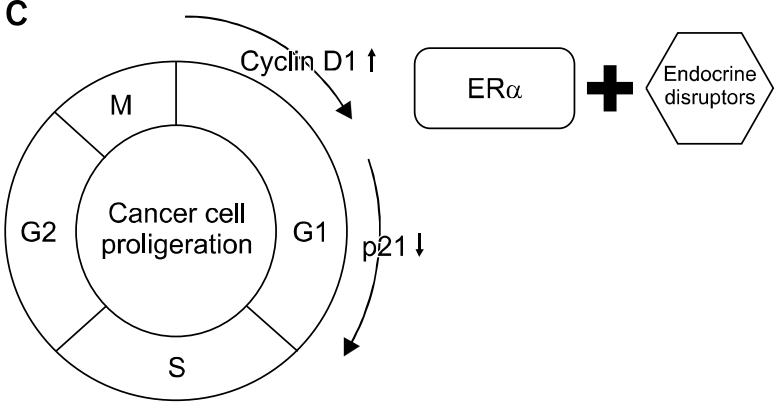

Figure 2. Common molecular mechanisms of endocrine disruptors. (A) Endocrine disruptors act as receptors (especially endocrine receptor) binding inhibitors. Most harmful effects are initiated by this inhibition and is shown by most endocrine disruptors mechanism. (B) When the targets of endocrine disruptors were adipocyte, endocrine disruptors can be obesogens. In this case, peroxisome proliferator activated receptor (PPAR) on mesenchymal cells or progenitor cells are the targets. (C) In the case of cancer, endocrine disruptors act on the cell cycle. Cyclin protein and p21 protein were known to regulate cancer cells when exposed to endocrine disruptors. ER, estrogen receptor; MSC, mesenchymal stem cell. Cited from the article of Celik et al. (Chem Res Toxicol 2008;21:2195-206), Masuno et al. (Toxicol Sci 2005:84:319-27), and Ohtsubo et al. (Mol Cell Biol 1995;15:2612-24). ${ }^{16-18}$

system. First, they can disrupt the action of enzymes involved in steroidogenesis. These enzymes can be inhibited, as can the enzymes involved in metabolism of estrogens. For instance, some polychlorinated biphenyl (PCB) metabolites inhibit sulfotransferase, resulting in an increase of circulating estradiol. ${ }^{19}$ The transport of hormones is also targeted by certain compounds capable of interacting with the binding sites of sex hormone binding globulin, thus competing with endogenous estrogens. ${ }^{20}$ The most studied mode of action of endocrine disruptors is their ability to bind and activate endocrine receptors (ERs) in target tissue. ${ }^{16}$ However, it is of note that the two ERs mediate distinct biological effects in many tissues, such as the mammary glands, bone, brain, and vascular system in both males and females. Therefore, because ER $\alpha$ and ER $\beta$ show different tissue distribution and distinct physiological functions, endocrine disruptors could display agonist or antagonist activity in a tissue-selective manner or during development. Considering the significant differences in structural features and relative ligand binding affinity of the ER subtypes, endocrine disruptors can induce distinct conformational changes in the tertiary structure of the ERs, affecting the recruitment of cofactors differently. These interactions between ERs and coactivators/corepressors are critical steps in ER-mediated transcriptional regulation and consequently the modulation of the expression of ER-target genes.

Moreover, the genistein effect is often tissue specific, depending on numerous factors such as the expression of specific cofactors, the ER $\alpha / \operatorname{ER} \beta$ ratio, and the level of expression of certain intracellular kinases, including cytoplasmic tyrosine kinases. Genistein has been reported to have both proliferative and anti-proliferative effects in cancer cells. ${ }^{21}$ Endocrine disruptors generally act in 100 to 1,000 folds greater concentrations than estradiol but can have additive or synergic effects with 
endogenous estradiol or when they are present in combination. ${ }^{22}$ Furthermore, the ability of some endocrine disruptors to act as agonists in certain tissues and as antagonists in the others leads to the development and use of selective ER modulators, in particular for anti-hormonal treatments, such as tamoxifen and raloxifene. Some endocrine disruptors can also affect the ER non-genomic pathways and induce an endocrine disruption. ${ }^{23}$ For instance, a study performed on structurally different endocrine disruptors showed that at high concentrations, BPA and diethylstilbestrol are able to activate ERs via the activation of mitogen-activated protein kinase and phosphotidyl inositol 3-kinase in breast cancer cells. In addition, the activation of protein kinase $\mathrm{C}$ (PKC) by some endocrine disruptors has been observed. ${ }^{24}$ Interestingly, PKC has been reported to modulate ER $\alpha$ transcriptional activity. ${ }^{25}$ Therefore, synergic or additive effects between these pathways to combine the activation of ER signaling could be possible.

Cadmium is well known as a endocrine disruptor which affects the synthesis and/or regulation of several hormones. ${ }^{26,27}$ Indeed, cadmium affected progesterone synthesis in JC-410 porcine granulose cells and activated the ER $\alpha$ and/or mimic estrogen in different tissues (e.g., uterus and mammary gland) and breast cancer cell lines. ${ }^{28-30}$ Cadmium regulates androgen receptor gene expression and activity in LNCap cells, a hormone-dependent human prostate cancer cell line, and also mimics androgenic effects in rats and mice. ${ }^{31}$ In male rodents, it is well established that cadmium significantly alters the circulating levels of several hormones (e.g., testosterone, luteinizing hormone [LH], and follicle-stimulating hormone $[\mathrm{FSH}])^{32}$ Moreover it decreased steroidogenic acute regulatory protein, LH receptor and cyclic adenosine monophosphate (CAMP) levels in the testis. ${ }^{33}$ Cadmium affected the circadian pattern release of noradrenaline, a regulator of hypothalamus hormone secretion, which resulted in changes in the daily pattern of plasma testosterone and $\mathrm{LH}$ levels. ${ }^{32}$ In addition, plasma levels of pituitary hormones (e.g., LH, FSH, prolactin, and adrenocorticotropic hormone) were modified after cadmium exposure. ${ }^{34}$

\section{Obesity mechanism}

Endocrine disruptors play another role in obesity and the metabolic programming of obesity risk. Their action predicts the existence of chemical obesogen, molecules that inappropriately regulate lipid metabolism and adipogenesis to promote obesity. Although until now, data have been scant; some epidemiological and in vitro studies suggested a link between environmental chemical exposure and obesity. ${ }^{35}$
The endocrine disruptors inducing obesity are called obesogens and have been reviewed. ${ }^{35}$ Obesogens have been shown to target transcription regulators found in gene networks that function to control intracellular lipid homeostasis as well as proliferation and differentiation of adipocytes. The major group of regulators that is targeted is a group of nuclear hormone receptors known as peroxisome proliferator activated receptors (PPAR $\alpha, \delta$, and $\gamma$ ). These hormone receptors sense a variety of metabolic ligands, including lipophilic hormones, dietary fatty acids, and their metabolites, and, depending on the levels of these ligands, control transcription of genes involved in balancing the changes in lipid balance in the body. ${ }^{36}$ In order to become active and properly function as both metabolic sensors and transcription regulators, the PPAR receptors must heterodimerize with another receptor known as the 9-cis retinoic acid receptor (RXR). The RXR receptor, itself, is the second major target of obesogens next to the PPAR receptors. ${ }^{35}$ The central regulator in this process is the PPAR $\gamma$, which associates with the RXR receptors and binds DNA targets as a heterodimer to directly regulate the expression at the transcriptional level. ${ }^{37}$ PPAR $\gamma$ is considered to be the master regulator of adipogenesis and plays key roles in nearly all aspects of adipocyte biology. ${ }^{38}$ It was recently proposed that PPAR $\gamma$ may function in adipogenesis without the need to be activated by a ligand. When the ligand binding domain of PPAR $\gamma$ was mutated such that the receptor was unresponsive to known agonists, the ability of preadipocytes to differentiate into adipocytes in cell culture was unaffected. ${ }^{39}$ The most reasonable interpretation of these data is that either PPAR $\gamma$ can act as an unliganded transcription factor to mediate adipogenesis, or that an as yet unknown endogenous ligand is being produced in response to the induction cocktail. Several endocrine disruptors are known to affect PPAR $\gamma$ activity and induce adipogenesis.

Notable among these are organotins such as tributyltin and triphenyltin and certain phthalates. ${ }^{40,41}$ Triorganotins and phthalates also have the ability to induce adipocyte differentiation in a variety of cell culture models. ${ }^{42,43}$ Other endocrine disruptors are known to promote adipogenesis, but probably do not act through PPAR $\gamma$. These include BPA, organophosphate pesticides, monosodium glutamate, and PBDEs. ${ }^{44,45}$ PCBs bind the aryl hydrocarbon receptor in adipocytes and increase adipogenesis. ${ }^{46}$ BPA and alkylphenols stimulate adipogenesis in 3T3-L1 cells, and BPA diglycidyl ether was recently shown to induce adipogenesis in human and mouse bone marrow-derived mesenchymal stem cells. ${ }^{17}$ Although several endocrine disruptors are associated with adipogenesis and obesity in animal models, tributyltin is the only endocrine disruptor known to cause in 
utero effects on adipocytes via activation of PPAR $\gamma^{47}$ Prenatal exposure to tributyltin in mice led to a substantial increase in the amount of triglycerides in newborn tissues which normally have little to no fat at all, although, the experiments did not distinguish whether more lipid was stored in existing cells, more cells were produced, or both. ${ }^{43}$ Other endocrine disruptors are likely to promote adipogenesis, in utero, although it is possible that this is secondary to broader metabolic imbalances. For instance, certain PCBs and PBDEs reduce thyroid function as does the antibacterial compound triclosan. ${ }^{48,49}$ The mechanisms of action are not completely certain, but possible modes include interference with thyroid hormone synthesis, transport, metabolism, or clearance. ${ }^{50}$

\section{Cancer mechanisms}

Various studies have explored the role of endocrine disruptors in cancer. Breast cancer and prostate cancer are typical cancers caused by endocrine disruptors and compelling reasons to study endocrine disruptors. ${ }^{50}$ Despite various studies that have been completed, the direct roles of endocrine disruptors in cancer have not been clearly understood. Many researchers inferred that physiological unbalance created by endocrine disruptors might cause cancer. Generally endocrine disruptors are more harmful to woman than man and endometrial cancer and ovarian cancer are being researched. ${ }^{51}$

Epidemiologic data on the effects of endocrine disruptors on endometrial cancer are limited. Researchers found no association between endometrial cancer and 27 PCB congeners, 4 dichlorodiphenyl-trichloroethane-related compounds, and 13 other organochlorine compounds. ${ }^{52}$ Several retrospective occupational cohort studies also observed no association. ${ }^{53}$ In the Seveso industrial accident, tetrachlorodibenzodioxin exposure appeared to reduce the risk of uterine cancer, but the number of cases was too small for a comprehensive evaluation. ${ }^{54}$

There is some evidence that dietary isoflavones protect endometrial proliferation. Controversially, a randomized doubleblind, placebo-controlled study on 298 post-menopusal women showed an increased incidence of endometrial hyperplasia following 5 years of treatment with $50 \mathrm{mg}$ of soy isoflavones. ${ }^{55}$ Thus, phytoestrogenic supplements should be reconsidered, particularly in women at high risk for endometrial cancer. Isoflavones are known as beneficial materials but they can be harmful to the body because these are actually endocrine disruptors.

Ovarian function is controlled by the hypothalamus, pituitary, and auto-paracrine factors. Hormone-mimicking compounds can bind to cell receptors, interfere with hormone action, and affect ovarian function. It is not clear how endocrine disruptors affect ovarian function, but a disruption in gonadotropin (i.e., FSH and LH) secretion and feedback mechanisms involving estradiol (E2) and progesterone (P4) may be involved.

Alternatively, endocrine disruptors may affect ovarian hormone production and oocyte maturation. Damaged oocytes can affect overall hormone production and follicular function, resulting in an endocrinological imbalance (i.e., a decrease in $\mathrm{E} 2$ and $\mathrm{P} 4$, but an increase in FSH and $\mathrm{LH}$ ) and ovarian failure. Ovarian cancer is the most prevalent type of gynecological cancer affecting women residing in Western countries. As more than $60 \%$ of tumors are diagnosed at stage III and certain forms of cancer are very aggressive, ovarian cancers are associated with a high mortality. While most cells undergo neoplastic transformation, including germ cells, granulose, and stromal cells, approximately $90 \%$ of tumors are derived from the ovarian surface epithelium. Similar to breast cancer, hormonal factors such as estrogen and xenoestrogens have been linked to ovarian cancer. ${ }^{56}$ However, the role of environmental toxins in ovarian cancer requires further study.

\section{DISCOVERY OF MOLECULAR MECHANISMS BY ENDOCRINE DISRUPTORS EXPOSURE USING PATHWAY ANALYSIS}

The biological pathways and processes that occur in a tissue are reflected in the gene expression profile of that tissue. Alterations in gene expression upon chemical exposure may result in phenotypic changes that relate to the mode of action of that chemical and any associated toxicity. The ability to determine which Gene Ontology terms and biological pathways are associated with differentially expressed genes from a microarray experiment, which we call gene ontology or pathway mapping, would therefore be an ideal way to gain an understanding of the molecular processes affected by the gene expression changes and so reveal information on mode of action and toxicity. Recently, many groups have developed methods and tools for pathway and gene ontology mapping that reveal statistically significant annotations associated with microarray data. In addition, several recent publications have used gene ontology to aid the interpretation of toxicogenomic data.

Three chemicals are focused on in this review: BPA, NP and DEHP (Fig. 3). ${ }^{18.57-82}$ These chemicals are typical endocrine disruptors and also the numbers of studies are the most 

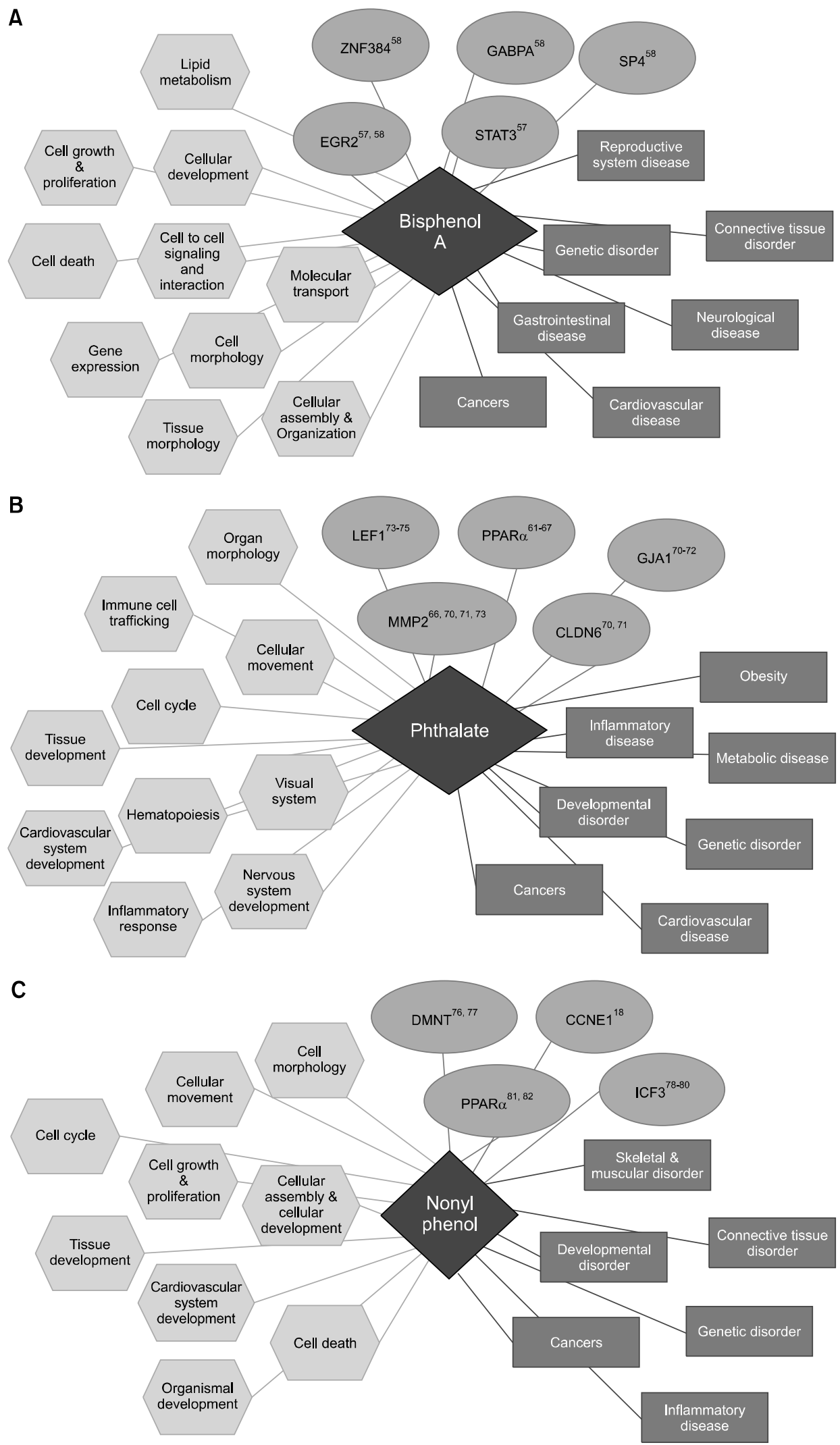

Figure 3. The related pathway of molecular/cellular process and disease/ disorder. (A) Bisphenol A. Included molecular/cellular process and diseases/disorders were collected from the relevant papers. ${ }^{57.60}$ (B) Phthalate. Included molecular/cellular process and diseases/disorders were collected from the relevant papers. ${ }^{61-75}$ (C) Nonylphenol. Included molecular/ cellular process and diseases/disorders were collected from the relevant papers. ${ }^{18.76-82}$ Each pathway was discovered using pathway analysis. Researchers can find the significant molecular and cellular pathway and compare and infer the correlation between the endocrine disruptors and the disease in terms of gene ontology. The pathway analysis can open up the possibility for more study. LEF1, lymphoid enhancerbinding factor 1; PPAR, proliferator activated receptor; ICF3, immunodeficiency-centromeric instability-facial anomalies syndrome 1 . 
abundant. In fact, some government agencies take these three chemicals as representative substances of all the endocrine disruptors. Researches show these chemicals can disrupt reproductive and developmental systems, increase cancer risks and damage the immune systems of experimental laboratory animals. $^{83}$

\section{Bisphenol A}

BPA is a carbon-based synthetic compound with the chemical formula $\left(\mathrm{CH}_{3}\right)_{2} \mathrm{C}\left(\mathrm{C}_{6} \mathrm{H}_{4} \mathrm{OH}\right)_{2}$, with two hydroxyphenyl groups belonging to the group of diphenylmethane derivatives and isphenols. It is a colorless solid that is soluble in organic solvents, but poorly soluble in water and has been in commercial use since 1957. A 2010 report from US Food and Drug Administration identified possible hazards to fetuses, infants, and young children. $^{84}$ The major human exposure route to BPA is diet, including ingestion of contaminated food and water. ${ }^{3}$ BPA is leached from the lining of food and beverage cans, where it is used as an ingredient in the plastic used to protect the food from direct contact with the can. ${ }^{85}$ BPA can enter the environment either directly from chemical, plastic coating, and staining manufacturers, from paper or material recycling companies, foundries who use BPA in casting sand, or indirectly leaching from plastic, paper, and metal waste in landfills or ocean-borne plastic trash.

BPA is an endocrine disruptor that can mimic estrogen and has been shown to cause negative health effects in animal studies. Early developmental stages appear most sensitive to its effects, and some studies have linked prenatal exposure to later physical and neurological effects. ${ }^{86}$ BPA has been proposed to increase the risk of obesity, brain diseases, disruption of the hormone system/ reproduction system, cancer, asthma, and heart disease. ${ }^{87}$

A few groups have used microarrays for in vivo studies of the effects of BPA exposure. Saili et al. ${ }^{57}$ studied the effects of BPA exposure in the development of zebrafish. They identified 26-genes affected by exposure to BPA and reported that those genes were related to the cAMP response element. Lam et al. ${ }^{58}$ also studied zebrafish to see the effects of BPA exposure, but focused on phenotype analysis. They defined 38-genes to suggest dose-dependent effects following BPA exposure and detected those genes involved in 11-molecular mechanisms. In vitro studies of BPA exposure followed. Yin et al. ${ }^{59}$ studied human embryonic kidney cells exposed to BPA. They identified 8-upregulated genes and 7-down-regulated genes significantly differentially expressed after BPA exposure. They confirmed that there were 15 molecular mechanisms acting. Qin et al. ${ }^{60}$ studied
BPA exposure with human foreskin fibroblast cells from hypospadias patients. Hypospadias is one of the most common congenital abnormality with a global prevalence of approximately $0.2 \%$ to $1.0 \%$ at birth in male infants. They identified 29-upregulated genes and 42-down-regulatedgenes after BPA exposure, suggesting related functions in response to BPA. They also constituted 5 groups of molecular mechanisms associated with those genes.

\section{Di-(2-ethylhexyl) phthalate (phthalate category)}

DEHP is an organic compound with the formula $\mathrm{C}_{6} \mathrm{H}_{4}$ $\left(\mathrm{C}_{8} \mathrm{H}_{17} \mathrm{COO}\right)_{2}$. It is the diester of phthalic acid and the branchedchain 2-ethylhexanol. Generally it has suitable properties and low cost DEHP is widely used as the plasticizer in manufacturing of articles made of Polyvinyl Chloride (PVC). ${ }^{88}$ Three billion kilograms are produced annually worldwide and its environmental exposure has been issue. It can be absorbed from food and water, with higher levels found in milk and cheese. ${ }^{89}$

DEHP is known as a potential endocrine disruptor, which can effect development, obesity, and cardiotoxicity. ${ }^{90}$ In general, the exposure of children to phthalates is greater than for adults because infants' and toddlers' mouthing behavior. ${ }^{91}$ For that reason much of current research on the effects of phthalate exposure has been focused on children's health. ${ }^{92}$ The relationship between obesity and endocrine disruption is a current issue. Phthalate metabolites showed statistically significant correlations with obesity and insulin resistance. ${ }^{93}$

The studies of pathway analysis with phthalate have mainly focused on the testis. Other studies have been conducted on in cancer cell lines and cardiac muscle cells. The focus on the testis is phthalate inhibits the action of testosterone as an endocrine disruptor. ${ }^{94}$ In the present study, 21 pathways were shown to change significantly due to phthalate exposure in testis. ${ }^{95-100}$ PPAR signaling pathway and $\mathrm{p} 53$ signaling pathway are among the 21 pathways as representative molecular mechanisms. A total of five genes consistently show to significant response to phthalate in several studies. ${ }^{61-65}$ The five genes are involved in steroid metabolism, and genes such as those may be an indicator of phthalate exposure. In other studies, cardiac muscle have been studied that associate cardiovascular disease with phthalate. The PPAR $\alpha$ is one common gene that significant changes in response to phthalate in cardiac muscle. ${ }^{66}$ PPAR $\alpha$ is a key regulator of lipid metabolism and a peroxisome proliferator. ${ }^{67}$ In fact, a lot of research on diseases, including cardiovascular disease, have been reported due to oxidative stress caused by phthalate. ${ }^{68,69}$ In in vitro tests, pathway analysis is being conducted. In testicular 
carcinoma cells treated with phthalate, three genes (GJA1, CLDN6, MMP2) were changed significant. ${ }^{70}$ GJA1 was significantly down regulated and CLDN6, MMP2 were significantly up regulated. It is known that all three genes, performing functions related to cell interaction. ${ }^{71}$ Several studies have been associated with disease and the above genes. ${ }^{72}$ Additional studies are required to study these genes. Pathway analysis related to phthalate has been studied in breast cancer cells as well as other cancers. ${ }^{73}$ When compared to the known existing cancer study, lymphoid enhancer-binding factor 1 (LEF1) is the most significant gene. LEF1 is well known to participate in the Wnt signaling pathway and may play a role in hair cell differentiation and follicle morphogenesis. ${ }^{74}$ Generally known to be found in normal thymus, it is found highly expressed in several cancer biopsy and cell lines. ${ }^{75}$ LEF1 might be a new indicator of cancer from phthalate exposure.

\section{Nonylphenol}

NPs are a family of closely related organic compounds called alkylphenols. They are used in manufacturing antioxidants, lubricating oil additives, laundry and dish detergents, emulsifiers, and solubilizers. ${ }^{7}$ These compounds are also precursors to the commercially important non-ionic surfactants alkylphenol ethoxylates and nonylphenol ethoxylates, which are used in detergents, paints, pesticides, personal care products, and plastics. NP has attracted attention due to its prevalence in the environment and its potential roles as an endocrine disruptor and xenoestrogen, due to its ability to act with estrogen-like activity. NPs act as xenoestrogen like endocrine disruptors by binding to estrogen receptors and competitively inhibiting natural estrogens. NPs have been shown to mimic the natural hormone $17 \beta$-estradiol and to compete with the endogeneous hormone for binding with estrogen receptors ER $\alpha$ and ER. ${ }^{7}$

Unlike other endocrine disruptors, pathway analyses with NPs are lacking. Pathway analysis with nonlyphenol has been studied in the seminiferous tubule, because NP is known to act on the testis. Pathway analysis was also studied in the immune system. In the present study, the researcher looked at the change of expression with DNMT3 (DNAcytosine-5-methyltransferase3) gene. ${ }^{76}$ DNMT3 is required for genome-wide de novo methylation and is known to be essential for the establishment of DNA methylation patterns during development. ${ }^{77} \mathrm{~A}$ representative disease associated with DNMT3 is immunodeficiency-centromeric instability-facial anomalies syndrome 1 (ICF3) where studies show limited hypomethylation of DNA in a small fraction of the genome in some patients. ${ }^{78,79}$ Another study about pathway analysis with NPs is focused on the change of miRNAs expression. ${ }^{80}$ They analyzed the miRNAs level changes in mouse sertoli cells exposed to NP, tracking the targets of miRNAs. Two genes (CCNE1, peroxisome proliferator-activated receptor $\alpha$ [PPARA]) showed associated change with miRNAs. In the CCNE1 (G1/S-specific cyclin-E1) case, the related disease is not known yet, but is known as an essential factor of the cell cycle at the G1/S (start) transition. ${ }^{18}$ The PPARA gene is known as a key regulator of lipid metabolism and as a ligand-activated transcription factor. $^{81,82}$ They also focused on one miRNA that was the most significantly changed, and analyzed the target genes of miRNA. Twenty genes were classified and those genes were related to cell cycle, cell death, cell morphology, cell-to-cell interaction/signaling and cellular assembly and organization.

\section{DISCUSSION}

Today, there are various diseases of unknown cause which endocrine disruptor has been implicated and research is needed. To measure and analyze hazardous materials is important. But it is difficult to define the molecular mechanisms that hazardous materials. In the case of endocrine disruptors which have various mechanisms, the process can be difficult. We have summarized the effects of endocrine disruptors and classified them into three classes: hormone disrupting, obesity related, and cancer related. With this classification, their molecular mechanisms are also identified. But the identified mechanisms were only general and do not cover all the specific mechanisms of endocrine disruptors. Bioinformatics can provide efficient methods to analyze and find molecular pathway. Indeed some researchers executed pathway analysis with endocrine disruptors and we looked at these in this review. Pathway analysis in bioinformatics can be applied under various conditions, but we only focused on the material condition. Because bioinformatics tools analyze experimental results, if pathway analysis have accessed other conditions researchers can get other results.

The ER signaling pathway and the PPAR signaling pathway are affected by endocrine disruptor. We can see two mechanisms in pathway analysis focused on material condition. However we can also propose other molecular mechanisms from pathway analysis. Researchers can study the disease in terms of different mechanisms other than the known mechanism. Pathway analysis not only shows various mechanisms of hormone disrupting, obesity and cancer, but also suggests other disorders and diseases related endocrine disruptors. If they parallel with experiments and bioinformatics tools, the direction of study on endocrine 
disruptors becomes clear.

In this review, we investigated the molecular mechanisms of endocrine disruptor related to hormone disrupting, obesity, and cancer. We focused on pathway analysis using bioinformatics tools from three endocrine disruptors: BPA, phthalate, and NP. By pathway analysis, the various molecular mechanisms were defined and the different disorders were suggested with endocrine disruptors. When discussed by analogy to these results, pathway analysis can be an efficient method to study molecular mechanism.

\section{ACKNOWLEDGMENTS}

This study was supported by a grant from 'The Ecoinnovation Project' (412-112-011), by the Korea Ministry of Environment. This study was also supported by Korea Ministry of Environment as 'Converging technology project'.

\section{CONFLICTS OF INTEREST}

No potential conflicts of interest were disclosed.

\section{REFERENCES}

1. National Institute of Environmental Health Science. Endocrine disruptors fact sheet. Available from: http://www.niehs.nih.gov/ health/materials/endocrine_disruptors_508.pdf. Accessed May, 2010.

2. Schecter A, Päpke O, Tung KC, Staskal D, Birnbaum L. Polybrominated diphenyl ethers contamination of United States food. Environ Sci Technol 2004:38:5306-11.

3. Cichna-Markl M. Sample clean-up by sol-gel immunoaffinity chromatography for the determination of bisphenol $\mathrm{A}$ in food and urine. Methods 2012;56:186-91.

4. Charles JW. Changes in indoor pollutants since the 1950s. Atmos Environ 2009:43:153-69.

5. Sharpe RM, Irvine DS. How strong is the evidence of a link between environmental chemicals and adverse effects on human reproductive health? BMJ 2004:328:447-51.

6. Bertelsen RJ, Carlsen KC, Calafat AM, Hoppin JA, Håland G, Mowinckel $\mathrm{P}$, et al. Urinary biomarkers for phthalates associated with asthma in Norwegian children. Environ Health Perspect 2013;121:251-6.

7. Soares A, Guieysse B, Jefferson B, Cartmell E, Lester JN. Nonylphenol in the environment: a critical review on occurrence, fate, toxicity and treatment in wastewaters. Environ Int 2008;34:1033-49.

8. Siu ER, Mruk DD, Porto CS, Cheng CY. Cadmium-induced testicular injury. Toxicol Appl Pharmacol 2009:238:240-9.

9. Järup L, Akesson A. Current status of cadmium as an environmental health problem. Toxicol Appl Pharmacol 2009;238:201-8.

10. Pappas RS, Polzin GM, Zhang L, Watson CH, Paschal DC, Ashley DL. Cadmium, lead, and thallium in mainstream tobacco smoke particulate. Food Chem Toxicol 2006:44:714-23.

11. Yeo MK. A study of effects and control policy of endocrine disruptors. Seoul, Korean Institute of Criminology, 2002.

12. International Food Safety Authorities Network. BISPHENOL A (BPA) - Current state of knowledge and future actions by WHO and FAO. Available from: http://www.who.int/foodsafety/publications/fs_management/No_05_Bisphenol_A_Nov09_en.pdf. Accessed November 27, 2009.

13. European Commission. Ban of phthalates in childcare articles and toys. Available from: http://europa.eu/rapid/press-release_ IP-99-829_en.htm?locale=en. Accessed November 10, 1999.

14. 110th Congress of the United States of America. An Act To establish consumer product safety standards and other safety requirements for children's products and to reauthorize and modernize the Consumer Product Safety Commission. Available from: http://www.gpo.gov/fdsys/pkg/BILLS-110hr4040enr/content-detail.html. Accessed August 1, 2008.

15. David A, Fenet H, Gomez E. Alkylphenols in marine environments: distribution monitoring strategies and detection considerations. Mar Pollut Bull 2009;58:953-60.

16. Celik L, Davey J, Lund D, Schiøtt B. Exploring interactions of endocrine-disrupting compounds with different conformations of the human estrogen receptor alpha ligand binding domain: a molecular docking study. Chem Res Toxicol 2008;21:2195-206.

17. Masuno H, Iwanami J, Kidani T, Sakayama K, Honda K. Bisphenol a accelerates terminal differentiation of 3T3-L1 cells into adipocytes through the phosphatidylinositol 3-kinase pathway. Toxicol Sci 2005;84:319-27.

18. Ohtsubo M, Theodoras AM, Schumacher J, Roberts JM, Pagano M. Human cyclin E, a nuclear protein essential for the G1-to-S phase transition. Mol Cell Biol 1995;15:2612-24.

19. Kester MH, Bulduk S, Tibboel D, Meinl W, Glatt H, Falany CN, et al. Potent inhibition of estrogen sulfotransferase by hydroxylated PCB metabolites: a novel pathway explaining the estrogenic activity of PCBs. Endocrinology 2000;141:1897-900.

20. Déchaud H, Ravard C, Claustrat F, de la Perrière AB, Pugeat M. Xenoestrogen interaction with human sex hormone-binding globulin (hSHBG). Steroids 1999;64:328-34.

21. Jagadeesh S, Kyo S, Banerjee PP. Genistein represses telomerase activity via both transcriptional and posttranslational mechanisms in human prostate cancer cells. Cancer Res 2006;66:210715.

22. Kortenkamp A, Altenburger R. Synergisms with mixtures of xenoestrogens: a reevaluation using the method of isoboles. Sci Total Environ 1998;221:59-73.

23. Watson PH, Pon RT, Shiu RP. Inhibition of c-myc expression by phosphorothioate antisense oligonucleotide identifies a critical role for c-myc in the growth of human breast cancer. Cancer Res 1991:51:3996-4000.

24. Li X, Zhang S, Safe S. Activation of kinase pathways in MCF-7 cells by 17 beta-estradiol and structurally diverse estrogenic compounds. J Steroid Biochem Mol Biol 2006;98:122-32.

25. Cho H, Katzenellenbogen BS. Synergistic activation of estrogen receptor-mediated transcription by estradiol and protein kinase activators. Mol Endocrinol 1993;7:441-52.

26. Henson MC, Chedrese PJ. Endocrine disruption by cadmium, a common environmental toxicant with paradoxical effects on reproduction. Exp Biol Med (Maywood) 2004:229:383-92.

27. Darbre PD. Metalloestrogens: an emerging class of inorganic 
xenoestrogens with potential to add to the oestrogenic burden of the human breast. J Appl Toxicol 2006;26:191-7.

28. Smida AD, Valderrama XP, Agostini MC, Furlan MA, Chedrese J. Cadmium stimulates transcription of the cytochrome p450 side chain cleavage gene in genetically modified stable porcine granulosa cells. Biol Reprod 2004:70:25-31.

29. Johnson MD, Kenney N, Stoica A, Hilakivi-Clarke L, Singh B, Chepko G, et al. Cadmium mimics the in vivo effects of estrogen in the uterus and mammary gland. Nat Med 2003;9:1081-4.

30. Brama M, Gnessi L, Basciani S, Cerulli N, Politi L, Spera G, et al. Cadmium induces mitogenic signaling in breast cancer cell by an ERalpha-dependent mechanism. Mol Cell Endocrinol 2007;264:102-8.

31. Martin MB, Voeller HJ, Gelmann EP, Lu J, Stoica EG, Hebert EJ, et al. Role of cadmium in the regulation of AR gene expression and activity. Endocrinology 2002;143:263-75.

32. Lafuente A, González-Carracedo A, Romero A, Cano P, Esquifino AI. Cadmium exposure differentially modifies the circadian patterns of norepinephrine at the median eminence and plasma LH, FSH and testosterone levels. Toxicol Lett 2004;146:175-82.

33. Gunnarsson D, Nordberg G, Selstam G. Differential effects of cadmium on the gene expression of seven-transmembranespanning receptors and GAPDH in the rat testis. Toxicol Lett 2007; 168:51-7.

34. Lafuente A, Cano P, Esquifino A. Are cadmium effects on plasma gonadotropins, prolactin, ACTH, GH and TSH levels, dose-dependent? Biometals 2003;16:243-50.

35. Grün F, Blumberg B. Endocrine disrupters as obesogens. Mol Cell Endocrinol 2009;304:19-29.

36. Grün F, Blumberg B. Minireview: the case for obesogens. Mol Endocrinol 2009:23:1127-34.

37. Tontonoz P, Hu E, Spiegelman BM. Stimulation of adipogenesis in fibroblasts by PPAR gamma 2, a lipid-activated transcription factor. Cell 1994;79:1147-56.

38. Tontonoz P, Spiegelman BM. Fat and beyond: the diverse biology of PPARgamma. Annu Rev Biochem 2008;77:289-312.

39. Walkey CJ, Spiegelman BM. A functional peroxisome proliferator-activated receptor-gamma ligand-binding domain is not required for adipogenesis. J Biol Chem 2008;283:24290-4.

40. Hiromori Y, Nishikawa J, Yoshida I, Nagase H, Nakanishi T. Structure-dependent activation of peroxisome proliferator- activated receptor (PPAR) gamma by organotin compounds. Chem Biol Interact 2009; 180:238-44

41. Feige JN, Gelman L, Rossi D, Zoete V, Métivier R, Tudor C, et al. The endocrine disruptor monoethyl-hexyl-phthalate is a selective peroxisome proliferator-activated receptor gamma modulator that promotes adipogenesis. J Biol Chem 2007;282:19152-66.

42. Kanayama T, Kobayashi N, Mamiya S, Nakanishi T, Nishikawa J. Organotin compounds promote adipocyte differentiation as agonists of the peroxisome proliferator-activated receptor gamma/retinoid X receptor pathway. Mol Pharmacol 2005;67:766-74.

43. Grün F, Blumberg B. Environmental obesogens: organotins and endocrine disruption via nuclear receptor signaling. Endocrinology 2006;147:S50-5.

44. Rubin BS, Soto AM. Bisphenol A: perinatal exposure and body weight. Mol Cell Endocrinol 2009:304:55-62.

45. Hoppe AA, Carey GB. Polybrominated diphenyl ethers as endocrine disruptors of adipocyte metabolism. Obesity (Silver Spring) 2007; 15:2942-50.
46. Arsenescu V, Arsenescu RI, King V, Swanson H, Cassis LA. Polychlorinated biphenyl-77 induces adipocyte differentiation and proinflammatory adipokines and promotes obesity and atherosclerosis. Environ Health Perspect 2008:116:761-8.

47. Kirchner S, Kieu T, Chow C, Casey S, Blumberg B. Prenatal exposure to the environmental obesogen tributyltin predisposes multipotent stem cells to become adipocytes. Mol Endocrinol 2010;24:526-39.

48. Hallgren S, Sinjari T, Håkansson H, Darnerud PO. Effects of polybrominated diphenyl ethers (PBDEs) and polychlorinated biphenyls (PCBs) on thyroid hormone and vitamin A levels in rats and mice. Arch Toxicol 2001;75:200-8.

49. Paul KB, Hedge JM, Devito MJ, Crofton KM. Developmental triclosan exposure decreases maternal and neonatal thyroxine in rats. Environ Toxicol Chem 2010;29:2840-4.

50. Diamanti-Kandarakis E, Bourguignon JP, Giudice LC, Hauser R, Prins GS, Soto AM, et al. Endocrine-disrupting chemicals: an Endocrine Society scientific statement. Endocr Rev 2009;30:293342.

51. Caserta D, Maranghi L, Mantovani A, Marci R, Maranghi F, Moscarini M. Impact of endocrine disruptor chemicals in gynaecology. Hum Reprod Update 2008;14:59-72.

52. Sturgeon SR, Brock JW, Potischman N, Needham LL, Rothman N, Brinton LA, et al. Serum concentrations of organochlorine compounds and endometrial cancer risk (United States). Cancer Cause Control 1998;9:417-24.

53. Sinks T, Henderson A, Blair A, Brown D, Staehling N, Humphrey $\mathrm{H}$. The mortality experience of people exposed to polybrominated biphenyls. Am J Epidemiol 1996;43:172.

54. Bertazzi A, Pesatori AC, Consonni D, Tironi A, Landi MT, Zocchetti C. Cancer incidence in a population accidentally exposed to 2,3,7,8-tetrachlorodibenzo-para-dioxin. Epidemiology 1993;4:398-406.

55. Unfer V, Casini ML, Costabile L, Mignosa M, Gerli S, Di Renzo GC. Endometrial effects of long-term treatment with phytoestrogens: a randomized, double-blind, placebo-controlled study. Fertil Steril 2004:82:145-8.

56. Brevini TA, Zanetto SB, Cillo F. Effects of endocrine disruptors on developmental and reproductive functions. Curr Drug Targets Immune Endocr Metabol Disord 2005;5:1-10.

57. Saili KS, Tilton SC, Waters KM, Tanguay RL. Global gene expression analysis reveals pathway differences between teratogenic and non-teratogenic exposure concentrations of bisphenol A and 17ß-estradiol in embryonic zebrafish. Reprod Toxicol 2013;38:89-101.

58. Lam SH, Hlaing MM, Zhang X, Yan C, Duan Z, Zhu L, et al. Toxicogenomic and phenotypic analyses of bisphenol-A early-life exposure toxicity in zebrafish. PLoS One 2011;6:e28273.

59. Yin R, Gu L, Li M, Jiang C, Cao T, Zhang X. Gene expression profiling analysis of bisphenol A-induced perturbation in biological processes in ER-negative HEK293 cells. PLoS One 2014;9:e98635.

60. Qin XY, Kojima Y, Mizuno K, Ueoka K, Muroya K, Miyado M, et al. Identification of novel low-dose bisphenol a targets in human foreskin fibroblast cells derived from hypospadias patients. PLoS One 2012;7:e36711.

61. Klinefelter GR, Laskey JW, Winnik WM, Suarez JD, Roberts NL, Strader LF, et al. Novel molecular targets associated with testicular dysgenesis induced by gestational exposure to dieth- 
ylhexyl phthalate in the rat: a role for estradiol. Reproduction 2012;144:747-61.

62. Vo TT, Jung EM, Dang VH, Yoo YM, Choi KC, Yu FH, et al. Di-(2 ethylhexyl) phthalate and flutamide alter gene expression in the testis of immature male rats. Reprod Biol Endocrinol 2009; 7:104.

63. Johnson KJ, McDowell EN, Viereck MP, Xia JQ. Species-specific dibutyl phthalate fetal testis endocrine disruption correlates with inhibition of SREBP2-dependent gene expression pathways. Toxicol Sci 2011;120:460-74.

64. Chauvigné F, Plummer S, Lesné L, Cravedi JP, Dejucq-Rainsford $\mathrm{N}$, Fostier A, et al. Mono-(2-ethylhexyl) phthalate directly alters the expression of Leydig cell genes and CYP17 lyase activity in cultured rat fetal testis. PLoS One 2011;6:e27172.

65. Plummer SM, Dan D, Quinney J, Hallmark N, Phillips RD, Millar $\mathrm{M}$, et al. Identification of transcription factors and coactivators affected by dibutylphthalate interactions in fetal rat testes. Toxicol Sci 2013;132:443-57.

66. Posnack NG, Swift LM, Kay MW, Lee NH, Sarvazyan N. Phthalate exposure changes the metabolic profile of cardiac muscle cells. Environ Health Perspect 2012;120:1243-51.

67. Mukherjee R, Jow L, Noonan D, McDonnell DP. Human and rat peroxisome proliferator activated receptors (PPARs) demonstrate similar tissue distribution but different responsiveness to PPAR activators. J Steroid Biochem Mol Biol 1994:51:157-66.

68. You H, Chen S, Mao L, Li B, Yuan Y, Li R, et al. The adjuvant effect induced by di-(2-ethylhexyl) phthalate (DEHP) is mediated through oxidative stress in a mouse model of asthma. Food Chem Toxicol 2014:71:272-81.

69. Zhou L, Beattie MC, Lin CY, Liu J, Traore K, Papadopoulos V, et al. Oxidative stress and phthalate-induced down-regulation of steroidogenesis in MA-10 Leydig cells. Reprod Toxicol 2013;42: 95-101.

70. Yao PL, Lin YC, Richburg JH. Mono-(2-ethylhexyl) phthalate (MEHP) promotes invasion and migration of human testicular embryonal carcinoma cells. Biol Reprod 2012;86:160, 1-10.

71. Liu XZ, Xia XJ, Adams J, Chen ZY, Welch KO, Tekin M, et al. Mutations in GJA1 (connexin 43) are associated with non-syndromic autosomal recessive deafness. Hum Mol Genet 2001;10:2945-51.

72. Richardson RJ, Joss S, Tomkin S, Ahmed M, Sheridan E, Dixon MJ. A nonsense mutation in the first transmembrane domain of connexin 43 underlies autosomal recessive oculodentodigital syndrome. J Med Genet 2006;43:e37.

73. Hsieh TH, Tsai CF, Hsu CY, Kuo PL, Hsi E, Suen JL, et al. n-Butyl benzyl phthalate promotes breast cancer progression by inducing expression of lymphoid enhancer factor 1. PLoS One 2012; 7:e42750.

74. Hovanes K, Li TW, Waterman ML. The human LEF-1 gene contains a promoter preferentially active in lymphocytes and encodes multiple isoforms derived from alternative splicing. Nucleic Acids Res 2000;28:1994-2003.

75. Jesse S, Koenig A, Ellenrieder V, Menke A. Lef-1 isoforms regulate different target genes and reduce cellular adhesion. Int J Cancer 2010;126:1109-20.

76. Ajj H, Chesnel A, Pinel S, Plenat F, Flament S, Dumond H. An alkylphenol mix promotes seminoma derived cell proliferation through an ERalpha36-mediated mechanism. PLoS One 2013;8:e61758.
77. Viré E, Brenner C, Deplus R, Blanchon L, Fraga M, Didelot C, et al. The Polycomb group protein EZH2 directly controls DNA methylation. Nature 2006;439:871-4.

78. Wijmenga C, Hansen RS, Gimelli G, Björck EJ, Davies EG, Valentine D, et al. Genetic variation in ICF syndrome: evidence for genetic heterogeneity. Hum Mutat 2000;16:509-17.

79. Jiang YL, Rigolet M, Bourc'his D, Nigon F, Bokesoy I, Fryns JP, et al. DNMT3B mutations and DNA methylation defect define two types of ICF syndrome. Hum Mutat 2005;25:56-63.

80. Choi JS, Oh JH, Park HJ, Choi MS, Park SM, Kang SJ, et al. miRNA regulation of cytotoxic effects in mouse Sertoli cells exposed to nonylphenol. Reprod Biol Endocrinol 2011;9:126.

81. Yan ZH, Karam WG, Staudinger JL, Medvedev A, Ghanayem BI, Jetten AM. Regulation of peroxisome proliferator-activated receptor alpha-induced transactivation by the nuclear orphan receptor TAK1/TR4. J Biol Chem 1998;273:10948-57.

82. Gorla-Bajszczak A, Juge-Aubry C, Pernin A, Burger AG, Meier CA. Conserved amino acids in the ligand-binding and tau(i) domains of the peroxisome proliferator-activated receptor alpha are necessary for heterodimerization with RXR. Mol Cell Endocrinol 1999;147:37-47.

83. Moggs JG. Molecular responses to xenoestrogens: mechanistic insights from toxicogenomics. Toxicology 2005;213:177-93.

84. U.S.Food and Drug Administration. Bisphenol A(BPA): Use in Food Contact Application. Available from: http://www.fda.gov/ NewsEvents/PublicHealthFocus/ucm064437. htm. Accessed January, 2010.

85. Goodson A, Summerfield W, Cooper I. Survey of bisphenol A and bisphenol F in canned foods. Food Addit Contam 2002;19: 796-802.

86. Health Canada. Survey of Bisphenol A in Canned Drink Products. Available from: http://www.hc-sc.gc.ca/fn-an/securit/packag-emball/bpa/bpa_survey-enquete-can-eng.php. Accessed March, 2009.

87. Rezg R, El-Fazaa S, Gharbi N, Mornagui B. Bisphenol A and human chronic diseases: current evidences, possible mechanisms, and future perspectives. Environ Int 2014;64:83-90.

88. Peter ML, Friedrich KT, Walter E, Rudolf J, Naresh B, Wolfgang $\mathrm{H}$. Phthalic acid and derivatives. In: Ullmann's Encyclopedia of Industrial Chemistry. New York, Wiley Interscience, 2007.

89. Sharman M, Read WA, Castle L, Gilbert J. Levels of di-(2-ethylhexyl)phthalate and total phthalate esters in milk, cream, butter and cheese. Food Addit Contam 1994;11:375-85.

90. Swan SH. Environmental phthalate exposure in relation to reproductive outcomes and other health endpoints in humans. Environ Res 2008; 108:177-84.

91. Sathyanarayana S, Karr CJ, Lozano P, Brown E, Calafat AM, Liu F, et al. Baby care products: possible sources of infant phthalate exposure. Pediatrics 2008;121:e260-8.

92. López-Carrillo L, Hernández-Ramírez RU, Calafat AM, TorresSánchez L, Galván-Portillo M, Needham LL, et al. Exposure to phthalates and breast cancer risk in northern Mexico. Environ Health Perspect 2010;118:539-44.

93. Desvergne B, Feige JN, Casals-Casas C. PPAR-mediated activity of phthalates: A link to the obesity epidemic? Mol Cell Endocrinol 2009:304:43-8.

94. Helal MA. Celery oil modulates DEHP-induced reproductive toxicity in male rats. Reprod Biol 2014;14:182-9.

95. Shultz VD, Phillips S, Sar M, Foster PM, Gaido KW. Altered gene 
profiles in fetal rat testes after in utero exposure to di(n-butyl) phthalate. Toxicol Sci 2001;64:233-42.

96. Barlow NJ, Phillips SL, Wallace DG, Sar M, Gaido KW, Foster PM. Quantitative changes in gene expression in fetal rat testes following exposure to di(n-butyl) phthalate. Toxicol Sci 2003:73:431-41.

97. Lehmann KP, Phillips S, Sar M, Foster PM, Gaido KW. Dose-dependent alterations in gene expression and testosterone synthesis in the fetal testes of male rats exposed to di (n-butyl) phthalate. Toxicol Sci 2004;81:60-8.

98. Thompson CJ, Ross SM, Gaido KW. Di(n-butyl) phthalate impairs cholesterol transport and steroidogenesis in the fetal rat testis through a rapid and reversible mechanism. Endocrinology 2004; 145:1227-37

99. Thompson CJ, Ross SM, Hensley J, Liu K, Heinze SC, Young SS, et al. Differential steroidogenic gene expression in the fetal adrenal gland versus the testis and rapid and dynamic response of the fetal testis to di(n-butyl) phthalate. Biol Reprod 2005:73: 908-17.

100. Plummer S, Sharpe RM, Hallmark N, Mahood IK, Elcombe C Time-dependent and compartment-specific effects of in utero exposure to Di(n-butyl) phthalate on gene/protein expression in the fetal rat testis as revealed by transcription profiling and laser capture microdissection. Toxicol Sci 2007;97:520-32. 